\title{
INTELLIGENTSIA SOCIALISM AND THE “WORKERS' REVOLUTION": THE VIEWS OF J. W. MACHAJSKI
}

The notion that the leadership of industrial society must eventually be ceded to an educated elite of technical and administrative experts is an important theme in the social thought of the last two centuries. It can be found as early as Saint-Simon's plans for the Systeme Industriel. As a criticism of the supposedly anti-proletarian aspects of Socialism it is commonly thought to have originated with James Burnham's idea of a "managerial revolution" and appeared later with Milovan Djilas's "new class". Actually the criticism of "State Socialism" in general, and of Marxism in particular, for an alleged tropism toward managerialism was also a weapon in the arsenal of nineteenth century anarchism. An integral part of Bakunin's criticism of Marx, whom he called the "Bismarck of Socialism", was the contention that Marxism in power would organize society "under the direct command of state engineers who will constitute a new privileged scientific-political class". ${ }^{1}$ This thesis has had its most consistent and rigorous formulation in the work of Jan Waclaw Machajski, a PolishRussian revolutionary who based his theory on the conviction that Socialism was not the ideology of the proletariat but of what he called the "intellectual workers", the new middle class of white collar employees generated by industrial capitalism. The most important antagonism in modern society, thought Machajski, was that between the educated - to whom he gave the inclusive term "bourgeois society" and the uneducated manual laborers. He argued that a portion of educated society, the Socialist intelligentsia with Marxists in the forefront, was attempting to gain for itself a privileged position in capitalist society by turning the labor movement away from direct action for higher wages and toward a struggle for parliamentary power which could only benefit the intellectual workers. If at long last, the parliamentary path should produce Socialism, Machajski warned, that would simply mean the rule of the intellectual workers under a system of nationalized industry. Political democracy thus

1 M. Bakunin, Izbrannie sochineniia (Moscow, 1922), Vol. I, p. 237. 
emerged in Machajski's theory as a force alien to the material interests of the working class. He suspected that the real concern of democratic Socialism was to save the national interest by suppressing not only capitalist particularism but the workers' interests as well.

Thus the triad Socialism-Democracy-Patriotism assumed in Machajski's mind an organic connection - the key to explaining the "opportunism" of both Revisionist and orthodox schools of European Social Democracy. A Socialist "general interest", he never tired of warning, was the mask for the class interest of the intellectual workers. Here again similarities with the Bakunist tradition are visible. Bakunin had seen conceptions such as the "public good" and the "will of the people" as contradictory to the workers' interests. "The state", he wrote, "has always been the patrimony of a privileged class: a sacerdotal class, a noble class, a bourgeois class and finally a bureaucratic class... it is the consolidated interest of this class which is called patriotism."1 Although Machajski never acknowledged a debt to this tradition, he worked out his theory of the intellectual workers in an attempt to separate what he, like Bakunin, had felt to be precious in Marxism the concept of class struggle - from its "opportunistic", "socialpatriotic" elements. While French revolutionary syndicalism was, at the time Machajski wrote, working out a similar updating of Bakunism by attempting to base its response to bourgeois society on the class struggle element in Marxism, Machajski could claim that he alone had coupled the tactics of syndicalism with an original class analysis of society based on an economic definition of the intelligentsia, the "national class" of Socialism. ${ }^{2}$

The revolutionary movement in Russian Poland was the first scene of Machajski's activity, curiously, as an intellectual worker, a Socialist, a Marxist and a Polish patriot. He was born near Kielce on December $15 / 27,1866$, the son of an impoverished clerk who died when Machajski was quite young. He attended gymnasium in Kielce where he met the young Stefan Zeromski who was to become one of Poland's greatest

1 M. Bakounine, Oeuvres (Paris, 1895), Vol. I, pp. 226-27.

2 That Machajski is known at all outside Russia and Poland is due to his former follower, Max Nomad. See his Aspects of Revolt (New York, 1959), ch. 5. Recent accounts include Paul Avrich, "What is 'Makhaevism'?", in: Soviet Studies (July, 1965), and Marshall Shatz, "The Conspiracy of the Intellectuals", in: Survey (January, 1967). I am grateful to Max Nomad for allowing me to use his materials on Machajski in his private collection and in the Internationaal Instituut voor Sociale Geschiedenis in Amsterdam. 
novelists. The two became close friends, an association which was to last, with frequent interruptions, through most of Machajski's life. While still in high school both the young intellectuals were attracted by the work of Jan Popławski who had founded Gtos, a Warsaw weekly turning out propaganda for the projected union of Prussian, Austrian and Russian Poland into one state. The editors of Gtos also attempted to expose the condition of factory workers and the rural poor to the educated reading public. This mixture of social radicalism and Polish patriotism was the predominant ideology of the young Machajski, but even before he was through high school he was troubled by a tension between the two elements. Zeromski reported in his Diaries that he and Machajski would often argue all night: "I defended patriotism and republicanism against the commune and cosmopolitanism."1 Zeromski's novel Syzyfowe prace (The Labors of Sisyphus) describes the patriotism of their high school days in conflict with the hostile atmosphere of the Russian school, an experience given its classic statement by Żeromski for a generation of young Poles. One of the book's leading characters is the young intelligent Andrzej Radek, who was modeled after Machajski but also painted with strong hues of Żeromski's own youthful patriotism, as in this reverie of Radek's:

"Each book he [Radek] brought [to clandestine meetings] was a novelty into which they threw themselves with the same curiosity with which today one reads the news in a recent daily about the latest events in the political world. So, what then says Dante in his 'Hell'? What writes Shakespeare in 'King Lear'? What is this 'Faust'? ... Often directly from 'Jerusalem Delivered' they proceeded to Eugene Sue or some British lady author whose name the Polish translator would not include with the title of the work, as though for protection of an honorable lady from compromise before the Public of 'Vistulaland' [Kraju Przywiślanskiego, a Tsarist usage for Poland], and with flaming zest deduced her character, stature and situation."2

Machajski and Żeromski met again at the University of Warsaw where they became involved in conspiratorial activity connected with the Zwiazek Mtodziezy Polski (Union of the Youth of Poland) known as "Zet", an auxiliary of the leading patriotic organization among the

1 Stefan Żeromski, Dzienniki (Warsaw, 1953), Vol. 1, p. 347. Also Stanisław Pigon, "Zygzaki przyjaźni", in: Miłe życia drobiazgi (Warsaw, 1964), p. 35.

2 Syzyfowe prace (Cracow, 1928), p. 267. The character of Radek impressed the young Polish Marxist, Sobelsohn, sufficiently for him to adopt the name - thus the later Bolshevik, Karl Radek. 
Polish exiles, the Liga Polska (Polish League). The Liga Polska believed that working class support would be an important asset in the struggle for Polish independence; consequently, its youth in Warsaw and other big cities conducted propaganda and educational activities among the workers in order to enlist their support. Machajski, however, had begun to question even more seriously than in his high school years the relevance of the national issue to the workers' interests. By around 1888 he had lost interest in his Zet activities and become attracted by the standpoint of the newly formed Gmina NarodowoSocjalistyczna (National-Socialist Commune). This group of Polish exiles in Paris was every bit as committed to Polish patriotism as Zet had been. But its leader, Bolesław Limanowski, insisted that the redemption of the Polish nation would only be possible under Socialism. Machajski saw in this National Socialism - a term which here received one of its early uses - little trace of the aristocratic exclusiveness he often encountered in Warsaw revolutionary circles. ${ }^{1}$ But he concluded that the social content of National Socialism existed only in the realm of ideas and had not advanced beyond "the sphere of the intelligentsia" sufficiently to create a workers' movement. The revolutionary students, he reported in Pobudka (Clarion), the organ of the Gmina, wanted to create such a bridge to the working class, but "we have by no means provided it with revolutionary socialist literature: we ourselves - one might as well admit it - have very sad ideas on these questions ..."2 He was arrested in Galicia in 1891, having been caught smuggling literature to Russian Poland, and confined for four months in Cracow, after which he was allowed to emigrate to Zurich. His disillusionment with Polish patriotism had deepened by this time. He came to conclude that

"The patriots remain socialists. But I feel that they do so only to draw the working masses into the fight for the 'fatherland'; these aristocrats do not think about the liberation of the working masses, but only about that of the Polish state."3

1 The Polish nationalist, Roman Dmowski, at the time of Machajski's arrest in Zakopane in 1911, writing in Gazeta Warszawska, described the period of Machajski's service in the national cause as a "conservative" or "traditionalist" phase, probably only in order to gain some sympathy for his old associate among Polish patriots. See Pigon, op. cit., pp. 356-57. Zeromski tried at the same time to present a similar picture.

${ }^{2}$ J. W. Machajski, " $Z$ życia Konspiracyjnego w Kongresówce", in: Pobudka (Paris), No 1 (January, 1892), p. 3.

"Quoted in Wiera Machajska, "Życie i poglądy Wacława Machajskiego", in: Wiadomości (London), No 831 (March 4, 1962), p. 2. 
Machajski's disillusionment with Polish patriotism was affected by the then current debate among the Polish Socialists. There existed two opposed tendencies. The first was a mixture of nationalist and socialist elements roughly consonant with the approach of Limanowski, having a great deal of support among the other exile groupings in London and Paris. Eventually these elements would provide the basis for the Polska Partya Socjalistyczna (PPS). The other trend comprised various groupings, the most important of which were the "Second Proletariat" - a revival of the Proletariat party founded by Ludwik Waryński in 1882 which was destroyed by the repressions of the later 1880's - and the Zwiqzek Robotników Polskich (ZRP) founded in 1889. The "Second Proletariat" and the ZRP were opposed to the patriotic position. In this sense they thought of themselves as heirs to the cosmopolitan tradition of the first Proletariat party and offered support to the strike movement then developing within Congress Poland. They would eventually form the Socjaldemokracja Królestwa Polskiego i Litwy (SDKPiL). ${ }^{1}$ The founding of the PPS was in part an attempt to fuse these two opposed currents, a possibility which was entertained by some of the cosmopolitans because of the failure of the strike movement of 1889-1892 in which they had placed large hopes. Not only Limanowski's National-Socialist Commune but also members of the Second Proletariat and the ZRP were part of the Zwiazek Zagraniczny Socjalistów Polskich (ZZSP) which organized the PPS in 1892.

The revival of the cosmopolitan opposition after the strikes of 1892 showed that the differences between the two basic trends had not disappeared. Machajski in 1891-92 completed the turn from patriotism which he had begun in 1888; he now thought of himself as a revolutionary Marxist and in the context of exile politics a supporter of the internationalist position. The May Day strikes of 1892, especially the "Lódż revolt", profoundly impressed him. ${ }^{2}$ He set out for Poland to spread revolutionary propaganda among the Lódż workers, but he was arrested en route. There followed three years of prison in Warsaw and St Petersburg and finally exile in Siberia. Thus, Machajski was forced to observe the developing contention between the PPS and SDKPiL from a vantage point in the Central Siberian Uplands. One of his fellow exiles later provided him with a library of Socialist literature, with which he attempted to analyze his Polish experiences.

To understand the development of Machajski's theories, it is

${ }^{1} \mathrm{~K}$. Grünberg and $\mathrm{C}$. Kozłowski, Historia Polskiego ruchu robotniczego, 1864-1918 (Warsaw, 1962), p. 90-97.

${ }^{2}$ Wiera Machajska, op. cit. For the other Polish radicals they showed that the reverses of 1889-92 had not been in vain. See Horst Schumacher and Feliks Tych, Julian Marchlewski (Warsaw, 1966), pp. 48-50. 
necessary to note that the PPS whose characteristics he saw echoed in the other Socialist parties, was a rather special case. The normal view of the PPS leadership was that national revolution was at least as important an element in the party's programs as was the accompanying social change such an overturn would bring. As later programs indicate, the social element could even be relegated to a back seat:

"First of all we see that [our program] does not in the least signify revolutionary socialism. The state expropriates only the largest proprietors and distributes land to the peasants on a long term lease ... There should not be any talk of organizing production under the state, the private ownership of the means of production will remain to a great degree unchanged, and the whole reform may be completed before a socialist government ensues. That is the slogan with which we go to fight the Tsardom."1

No one could challenge the willingness of the PPS to use force in the revolutionary cause, but there was always the question of whether such force was as welcome when it might not benefit the national movement. "The masses want freedom, changes, reforms, thus they are for revolution", PPS pamphlet claimed, warning against "some obscure revolutionary excitement, which may be easily directed into paths false and inimical to the revolution". ${ }^{2}$ There was, however, no such moderation on the question of national independence. Patriotic socialism would not be satisfied with autonomy within a federated Russian empire:

"The possessing classes do not want a fight; they may be satisfied with anything. Autonomy, that is the granting of certain laws by a conquering power, is for them the summit of day dreams. A revolutionary proletariat can never be satisfied with that; it fights for full national and political freedom, for a republic and independence." 3

The PPS synthesis was meant to include Marxists as well as other Socialists, but its vision of Socialism was inseparable from its drive to realize Polish independence. Machajski's understanding of Socialism was strongly effected by the fact that his only practical work up to the

1 A. Wroński [Witold Jodko], Program rolny PPS (Cracow, 1909), p. 21.

${ }^{2}$ Polska Partya Socjalistyczna, Anarchizm a bandytyzm (Warsaw, 1906), pp. 20-21.

3 "Res" [Feliks Perl], Patrjotyzm a socjalizm (Cracow, 1909), p. 21. 
time he wrote the essays that form the basis of his major work. The Intellectual Worker (Umstvennyi rabochii) had been in the Polish movement. His interpretation of the fate of Polish Socialism may, therefore, serve as an introduction to his critique of European Social Democracy.

An essay he hectographed and distributed among the exiles in 1898, The Evolution of Social Democracy, approaches the question of Polish Socialism largely from a standpoint quite close to, but not identical with, that of the revolutionary Marxists of the ZRP and the Second Proletariat. According to Machajski, Russian Poland was vastly more advanced in industrial development than the rest of the Russian Empire. Its bourgeoisie could thus collaborate with the Tsardom in order to exploit the potential Russian market for Polish manufactured goods; from this collaboration had come the intellectual and literary movement known as Positivism. With the slogan of "organic work" (praca organiczna) Positivism had set the goals of "patriotic culture, science and progress". ${ }^{1}$ Its real goal, Machajski thought, was a peaceful sharing with Tsarism of the "national surplus value" (natsional' naia pribavochnaia stoimost') which the cosmopolitan Proletariat party of the 1880 's had threatened. The failure of the "cosmopolitan socialists" had taught the intelligentsia that the best way to succeed was not through the strike movement, but by recourse to patriotism. To the working class the intelligentsia held out not higher wages but political freedom and national independence as the ends of the Socialist movement. Thus it was Socialism which in the 1890's 'infused new life into Polish patriotism". ${ }^{2}$ In the tradition of the National Socialism of Limanowski, it had subordinated the workers' interests to "generalnational goals" (obshchenatsional'nye tseli).

The Łódż general strike of 1892 had been, in Machajski's opinion, such an unexpected fact for Polish Socialism that it had not even published a single proclamation at the time of the strike. ${ }^{3}$ This was particularly galling in view of his conviction that the "Iódż revolt" had shown the Polish workers to be at a high state of revolutionary potential, an impression which was reinforced by the strikes in

1 A. Vol'ski [J. W. Machajski], Umstvennyi rabochii (Geneva, 1905), Part I, p. 41. Machajski here refers to the school of political thinking post-1863, which based itself on a philosophical application of Comte's Positivism to the Polish scene. Its leading proponents, men like Aleksander Swiętochowski, emphasized the "positive" aspects of the Polish predicament - the possibility for peaceful economic progress within the Empire - as against the purportedly romantic tradition of patriotism.

2 Ibid.

3 Ibid., pp. 42-43. 
Częstochowa in 1894, Białystok in 1895, and Dąbrowa in 1897. And because the PPS put patriotism first, a Polish revolution would be evaluated primarily for what it could contribute to the expected bourgeois revolution in Russia. By breaking the links to Poland's industries, the achievement of national independence could deal a powerful blow to the Russian empire. But this view, Machajski warned, assigned to the Polish proletariat a subordinate role in an upheaval which would be at best a sideshow compared to the anticipated larger Russian drama. It would, moreover, squander the strategic importance of the Polish working class, which would then presumably operate in the context of a much more limited, perhaps not even viable market of an independent Poland. ${ }^{1}$ It followed that the Polish proletariat must liberate itself from its PPS-assigned role of "eastern outpost of European Socialism". ${ }^{2}$ Rather than merely assist a political revolution, the Polish workers could and should lead a social revolution which would spill across the existing national boundaries, if they were led by revolutionary Marxists who did not follow the stale orthodoxy emanating from Kautsky and the German party.

As for the PPS, it had tried to "repeat every letter of the policy of German Social Democracy"." Leaders of the rank of Kautsky and Plekhanov had preferred to support these rather than true revolutionaries, even to the point of encouraging their return toward patriotism. " Just as the "szlachta" had formerly used patriotism to control the peasants, so now the Socialists would be using it to control the workers. Worse than that, having infected the workers' movement with nationalism, these Socialists would make it imperialist, as an independent Poland could not hope to exist outside the Russian market. Here Machajski attributed particular significance to two facts: that many members of the gentry ruined by the national movement of 1863-64 had ended up in the ranks of the intelligentsia; and that the patriotic Poles also envisioned separatist movements among the White Russians, Ukrainians and others. He accused the Socialists of making common cause with the "szlachta" elements who had brought with them "the whole baggage of national traditions" and who, he feared, would soon be calling for an annexationist campaign

1 The emphasis on the role of the larger Russian market is a point common to his and Rosa Luxemburg's criticisms of Polish "social-patriotism", for example, in her article "From Stage to Stage", in: Neue Zeit, No 6 (1897-1898), pp. 164176, with Kautsky's appended note that "We do not support its entire standpoint." For a Polish critique, see "Res" [Feliks Perl], Kwestya polska w oświetleniu "Socyaldemokracyi" polskiej (Warsaw, 1907).

"Umstvennyi rabochii, Part I, pp. 44-49.

3 Ibid., p. 44.

4 Ibid., p. 42. 
to the east to fulfill the old slogan of "Poland from sea to sea". 1

Had Machajski not gone any further than this, his analysis could have passed for a sharp piece of criticism of Social Democratic "opportunism", strong even for the most radical Marxists, but not entirely out of their orbit. That is perhaps one of the reasons why the first essay, whose implications were not immediately recognized, received so much attention among his fellow exiles. ${ }^{2}$ In the conclusion to the "Evolution of Social Democracy" which he wrote later he went on to suggest that the social forces supporting such opportunism could not all be classed under the rubric of "petty-bourgeois". Further economic development would, he felt, normally sweep away the nationalist aristocrats, the rural smallholders and lower middle class elements who were clinging to the PPS and pushing it into the defense of Catholicism, the peasantry, etc. But a growing element in the constellation was the Socialist intelligentsia. Comprised of members of the professions, journalists and would-be managers and officials, its numbers could only increase with the spread of education. Thus in Poland the patriotic crusade could not stop at autonomy but must seek full national independence because it was at bottom an attempt to take over the functions of the bureaucracy, the army and other areas of public life then occupied by Russians. The intelligentsia, defined in socio-economic terms as possessors of sufficient education to be able to avoid manual labor, the "white hands" of syndicalist invective, was a firm supporter of capitalist industrial development. It was, therefore, "progressive". The alliance for which it provided the keystone was likely to achieve the long term defeat of the proletariat, which had nothing to gain from the smaller market promised by patriotism.

1 Ibid., pp. 43, 45. Also J. W. Machajski, Bankrotstvo sotsializma XIX stoletiia (Greneva, 1905), p. 8; and Burzuazyina rewolucya a sprawa robotnicza (Geneva, 1905), p. 4-5. By "szlachta", Machajski refers not to the historic aristocracy which ruled Poland up to the partitions but rather, figuratively, to the remains of the patriotic landowning class.

2 The excitement caused by Machajski's ideas upset another exile, Trotsky: "For several months the work of Makhaiski [Machajski] was in the center of attention of the Lena exiles. Bold in its verbal negations, but lifeless and cowardly in its practical conclusions, it provided me with a strong inoculation against anarchism." Leon Trotsky, Moia zhizn' (Berlin, 1930), p. 154. Trotsky ran into the Makhaevist heresy at numerous points in his life and he always pointed out that Machajski was its originator, as in The Soviet Union and the Fourth International (New York, 1934), pp. 17-19, in which he continued to insist that bureaucracy was only "the political technique of class rule". One of his last political acts in 1939 was to anathemize James Burnham, then groping toward the idea of the "managerial revolution". 
Thus it was from the context of the East European revolution that Machajski provided his theory of the social basis of Social Democratic "opportunism". Among the peculiarities he had discerned from this context were the moderation of demands by Polish Socialists for immediate economic improvement, despite the increasingly "advanced" nature of the proletariat, the linkage between aristocratic and intelligentsia political objectives, and the "comprador" position of the bourgeoisie. But the most important thing to note here is that the circumstances of a revolutionary movement so deeply embroiled with the question of patriotism were those which led him to the economic definition of the intelligentsia and to his "class analysis" of Socialism itself. The intellectual workers' strategy of political revolution would prove to be technologically retrograde; this alone was reason enough for revolutionary Marxists to oppose it. While other radical Marxists were interpreting Social Democratic "opportunism" in terms of a confluence of different factors - including bureaucratism, the relative privilege of skilled labor in the union movements, and imperial expansion - the socio-economic definition of the intelligentsia seemed to offer an explanation of these diverse problems with a "technical" basis. Kautsky himself offered this as an explanation of revisionism.

The intelligentsia's claim that it alone could fully protect the national interest, that its unique position in society enabled it to "rise above the narrow class horizon", in Kautsky's phrase, was to Machajski the clearest proclamation of a prospective ruling class. In politically backward countries its circumstances might necessitate a political revolution, in order to provide favorable conditions for the development of bourgeois society (in which he included the intelligentsia), but once past the bourgeois revolution these former revolutionaries would do their fighting in the arena of "politics" - the institutions of political democracy. This then, was the goal of their workers' organizations:

"Many of the socialists assure us that, for the preparation of the workers for socialist life, all kinds of producers' and consumers' cooperatives will be especially useful, developing the solidarity of the workers and teaching them to lead the general economy. The Social Democrats add further that the workers must learn to manage the government and that in their political unions, their electoral campaigns, their parliamentary factions in different elected posts and city dumas and rural committees - the workers will gradually seize power from the bourgeoisie and, together 
with this, gain the knowledge necessary for running the government."1

But the workers could never hope to gain education sufficient to raise them to an equal level with the bourgeoisie by means of their "peoples' universities"; workers' education, therefore, was a fraud. As the example of German Social Democracy was understood by Machajski, it convinced him that the involvement of workers in the political and educational institutions of legal trade unions ended in the perpetuation of their subordinate status as troops for the Socialist politicians.

"For the workers it is necessary to seize the wealth of the whole world but the socialists advise them to tear a few pennies (groshi) from their slave-hunger rations in order to construct, on these pennies and these professional and cooperative societies, a future paradise." 2

When Machajski began the analysis of the Evolution of Social Democracy he had intended a critique from the perspective of revolutionary Marxist internationalism, in order to demonstrate scientifically the betrayal of Marxism by European Social Democracy. In the process, however, he had developed the hypothesis of the "class" of intellectual workers and its struggle to annex the "national surplus value". The next step, an analysis of that struggle, turned him against Marxism. An elaborated edition of his earlier works fitted with an introduction and a conclusion, was published in Geneva in 1905 and in St Petersburg in 1906 as part of his Intellectual Worker. "The initial attempt of the present investigation", he wrote in the introduction, "lay in the enterprise of a critique of Marxism on Marxist grounds."3 The first essay had begun, he said, by unmasking Social Democracy as a reflection of causes productive of an opportunism which ". . . reveals itself not only in the future leader of Revisionism, but also in the most correct of the orthodox". From there, he was driven to find its germ in the thought of "the very founders of scientific socialism, and at that, not only in their later works, in the clearly opportunistic papers of Engels in the 1890's, but also in the models of Marxist revolutionism, such as the Communist Manifesto."4

According to Machajski, the Manifesto had indeed contained the ultimate revolutionary strategy - that of "despotic inroads on the

1 Rabochii zagovor, Geneva (September-October, 1907), pp. 48-49.

2 Ibid.

3 Umstvennyi rabochii, Part I, p. iv.

4 Ibid. 
right of property"; alongside this, however, there were also two positions strongly restricting its meaning. These were: first, that Communists should work for the unity of democratic parties everywhere; and, second, that the first step in working class revolution is "to raise the proletariat to the position of a ruling class, to win the battle of democracy". ${ }^{1}$ This foreshadowed the degeneration of the Communism of the Manifesto into the democratic strategy of the International. Representative democracy was a cause alien to the proletariat. The "representatives" would be intellectual workers ruling in the name of a general or national interest which could only serve educated society. The workers were nowhere a majority, and a democratic strategy was not in the workers' interest, for either a despotic or a democratic society's first "national interest" was "order". Marx in the Eighteenth Brumaire had not appreciated the extent of the antagonism of the June days of 1848 , when the revolutionary proletariat had been defeated by what Marx had called the "party of order" - by all of bourgeois society. Actually the workers had been opposed not simply by the capitalists, as the Communist Manifesto had supposed, but by all educated society. The educated employees of the bourgeoisie had, at that time, fought alongside the bourgeoisie against the revolutionary workers. This battle between the educated bourgeoisie, defending society as a whole, and the proletariat, defending its own interest, was a microcosm of Machajski's dualistic world view - of "the gulf between the democratic cause and the cause of the proletariat". 2

In addition to defending the slow progress of the capitalist order, the intellectual workers had another reason to support the interest of society as a whole - the "democratic cause"; only a regime which could "rise above the narrow class horizon" could prevent the workers from making incursions on the "national surplus value". Even under Socialism the Marxists would hold this fund intact because it was precisely the source of the intellectual workers' privileged existence. Machajski therefore set out to provide his own "critique of political economy" by exposing what he claimed had been the real aim of the second volume of Capital - the justification of the intellectual workers' theft of the "national surplus value". His primary motif was the association of Marxist political economy with the ideas of Karl Johann Rodbertus, the German economist of the 1840's and 1850's and proponent of conservative or "feudal" socialism, singled out for attack by Marx as early as the Communist Manifesto. Rodbertus had held the

1 Ibid., pp. 19-20.

Ibid., p. 21. 
labor theory of value in a form which allowed him to propose an elaborate system of calculated rewards to manual workers according to "socially necessary" labor time. In his version of Socialism, workers would be paid in a special labor currency; wages and prices would be fixed by law and managed by a powerful state, which alone, Rodbertus had thought, could properly control the economic life of a modern society. Two volumes of his writings were published under the title Zur Beleuchtung der sozialen Frage (Light on the Social Question) in 1885, the same year as the appearance of the second volume of Capital. The similarity of some of the central notions of the two writers was not unknown to Victorian criticism of Marx. The latter had taken great pains to dissociate himself from many of Rodbertus' ideas, especially the "underconsumptionist" interpretation of business cycles (which laid great responsibility on the management of wages - a notion which would understandably appeal much more to a Lassalle than to a Marx). Engels, in his preface to the second volume of Capital was at some pains to refute Rodbertus's claim to be the originator of the theory of surplus value; he warned further, "When book three appears, little mention will be made of the economist called Rodbertus."1

Machajski claimed to discern a basic kinship between Marx and Rodbertus, principally in their concern for the "perpetual existence of national capital", with all that implied, namely a centralized industrial order managed by those possessing the requisite technical knowledge. Both writers thought a politically independent bourgeoisie incapable of filling this role. Machajski seized on Marx's claim (actually made in opposition to Rodbertus) that, since it was impossible to determine the actual product of each worker owing to the complexity of the modern division of labor, the whole of the product ought to accrue to the working class as a whole. Thus it might have seemed that Marx had asserted the material interests of the proletariat in a system of economic equality. But according to Machajski, Marx and Engels had provided that "a classless society, having seized from the hands of the capitalists their function of 'accumulation', may not, however, abolish it."2 Apparently, the Teachers intended merely to rescue the "national surplus value" from capitalist particularism by bringing it under the unitary control of the managers of the Socialist economy. This was the explanation for Marx's reverence for the growth of "constant capital" and his attribution of profits to the sphere of "variable capital" - that is, that these profits represented

${ }^{1}$ Engels, Preface to 1885 edition, Karl Marx, Capital, Vol. II (Moscow, 1967), p. 20.

2 Umstvennyi rabochii, Part II, pp. 3-4. 
the unpaid product of the workers' labor rather than a return on the addition to the existing physical plant. This "constant capital" was to be the foundation of the socialist "profitless" organization of society which Marx envisaged. ${ }^{1}$

Machajski's point, then, was that the workers would be exploited as much by socialist investment and its "costs" - among which were the salaries of the intellectual workers - as by capitalist profit. As long as the workers were prevented from making incursions on this national surplus, they would be condemned to manual labor, never able to gather the personal income necessary to educate their children. Marx's doctrine, therefore, was in essential agreement with Rodbertus' which "having as its goal the establishment of perpetual national capital, is the doctrine of the perpetual incommensurability of social product by social income."2 Rodbertus need not have been horrified, said Machajski, to hear Marx speak of the "class" demands of the proletariat.

"Had Rodbertus been able to see the second volume of Capital, he would have realized that there had been no reason for sharp objections to Marx - that Marx too realized the impossibility of the product ever passing into the hands of the workers."3

It can hardly be said that Machajski demonstrated by such an exercise the logic (whatever the likelihood) of the proposition that "educated society is the consumer of purely national profit". ${ }^{4}$ However, the "incommensurability" was insured, in Machajski's argument, by Marx's theory of the "dual character of labor power" which allowed him to distinguish between labor power of greater and lesser utility. This was the basis for Marx to provide for wage differentials under Socialism. Machajski suspected that these differentials might not only apply to manual labor:

"At a certain point complicated labor ceases to be labor of mechanical performance, in a broad sense, and becomes labor engaged in directing, managing, superintending the entire laboring process of society."5

1 Ibid., Part II, pp. 18-22. Machajski, like Marx, adhered to the labor theory of value. The portion of the national capital fund allotted to costs of management is traced by him back to the unpaid increment of value produced at the worker's bench. This was, after all, intended as a rigorous use of the method which Marx had cunningly refrained from using to analyze Socialist accumulation.

2 Ibid., Part II, p. 18.

Ibid., Part II, p. 4.

4 Ibid., Part II, p. 42.

5 Ibid., Part I, Conclusion, pp. 81-82. 
Thus to allow for higher wages to be paid for skilled labor was to open the door for the intellectual workers.

Machajski was led to such conclusions by the same habits of thought which saw the formation of surplus not in the overpricing of goods but in the underpayment of labor, therefore, the expropriation of the "unpaid labor" of the worker. If the Marxist justification for wage inequality rested in part on the costly nature of skilled labor and its higher productivity, it was consistent with a desire to develop aggregate output to the optimum. This, however, was Machajski's precise point: Marxism was saturated with visions of such aggregates which could only be supported and developed by goading the workers in the same way as the capitalists had done and by the maintenance of a parasitic upper layer of intellectual workers supported by "the unpaid product of other people's labor". ${ }^{1}$

This critique of Marxist economics was offered as the second part of The Intellectual Worker; it is of interest for the economic side of the Makhaevist (from the then common corruption of Machajski into "Mahkaev") heresy, although because of its difficulty it could not have won him many converts. Machajski apparently had no interest in creating a Capital of his own; he concluded that it was simply a blind of Marxism to have presented its economic doctrine as the last word in social science. Such "socialist science" was, he claimed, as much an ideological need of modern society as classical economics had been for capitalism.

"To show that the basic position of Rodbertus on the inequality of the social product and income, serving. . . as a source of the perpetuation of capital, is an irresistible truth of 'pure science', political economy, - such was the task of the second volume of Capital. This truth of Rodbertus rested not on his obscure conceptions, but on the incomplete foundations of the 'newest political economy' which was already, to boot, a 'pure proletarian' science."2

Such a firm "scientific" foundation was by no means necessary to recognize exploitation, Machajski argued in the manner of Bakunin, but was designed by Marx simply to heighten the aura of authority with which "socialist science expresses its religious fiction of one humanity with one necessity". In this way Marxism became the advocate of bourgeois society before the court of history. ${ }^{3}$

1 Ibid.

2 Ibid., Part II, p. 22.

s Bankrotstvo sotsializma XIX stoletiia (Geneva, 1905), p. 10. 
The really revolutionary element in Marxism - the doctrine of class struggle - was thus submerged into a kind of social holism which, Machajski insisted, was entirely inconsistent with and hostile to a truly proletarian outlook. Moreover, the corruption was not, he argued, simply a product of the development of Marxism into a "scientific" critique of Political Economy. Marxism had been poisoned at the roots by its development from German philosophy. Its truly revolutionary aspects resulted from those moments when the Teachers had recognized the depth of the social antagonisms of modern society for example, when they compared modern wage workers to ancient slaves. ${ }^{1}$ But, at bottom, Marx was trying to connect the subject of philosophy with the subject matter of the labor movement, in order for philosophy to become the "head" and the proletariat the "heart". Thus the materialist outlook with which Marx had attempted to rout German idealism was not a fully developed class position of the proletariat but rather an imperfect "philosophical" or "Feuerbachian" materialism which simply sought to put the "subjective utopianism" of the Young Hegelians on a firmer basis. ${ }^{2}$ The insufficiency lay, according to Machajski, in the fact that Marx brought to the task only a more materialist Hegelian version of the historical process, the view that history even in moments of darkest reaction was liberating mankind "through the development of the productive forces of humanity". ${ }^{3}$ Consequently this fetishizing of the historical process and the "productive requirements of humanity" had not produced a real materialism but had simply replaced "subjective utopianism" with an "objective utopianism" promising the proletariat "a heaven on earth as the result of the next historic adventure".4

In Machajski's eyes, Marxism's real function, despite its radical phrases, was to provide a means whereby the proletariat might appear as the most disciplined servant of "general-national needs". ${ }^{5}$ It was clear that

"The Marxist doctrine concerning the productive needs of society, the productive needs of humanity, is anything but economic materialism because this materialist viewpoint is not the real class position of the working masses but the old utopian standpoint of one society, one humanity."6

'See Machajski's "Primechaniia perevodchika" to K. Marx and F. Engels, Sviatoe Semeistvo (St Petersburg, 1906), 2 vols, pp. 39-63, for the argument described above.

Ibid., p. 44.

3 Ibid., p. 43.

Ibid., p. 48 .

5 Ibid., p. 54

I Ibid., p. 47. 
Marxism must, therefore, continually revert to an idea of general interest in order to explain the development of human freedom from the historical process. One could not have both a proletarian standpoint and the historical standpoint of Marx.

In adopting the latter, Marxism had turned away from the task of liberating the workers. Instead, Machajski thought, it had become the worship of necessity, imagining the industrial process to be a vast system of "unwitting collaboration". By telling the uneducated workers that they were being exploited by "forces of production" the Marxists were attempting to blunt their awareness of human agency in modern "predatory society" - an awareness of the power of the workers' will as opposed to the "laws" of social science. Machajski's harsh insistence on the power of the will was not simply anti-intellectualism. His theory of the intellectual workers showed that this grouping was not declining, like the "handful of capitalists at the top of society", but expanding constantly with industrial growth. Not only Marxism, but history itself was working against the proletariat. ${ }^{1}$

\section{III}

For Makhaevists, the thesis of the intellectual workers explained the increasingly reformist character of the Social Democratic parties, particularly the German party. The common assumptions of Marx and Rodbertus foreshadowed attitudes which had made Germany what Bülow called "a well-tended garden". Rodbertus's example demonstrated further that it was possible to work out a project for a socialist society in the interest of the possessing classes, a society in which high incomes would attach to a "privileged minority, recruiting itself from its progeny". ${ }^{2}$ There was, therefore, a logical continuity from Rodbertus to other German opponents of laissez-faire, particularly the "Socialists of the Chair" (Kathedersozialisten) of the 1870's and

\footnotetext{
1 Similar pessimistic conclusions about the growth of the middle layers of society can be found in anarchist literature. See V. Cherkezov, Doktriny Marksizma: nauka-li eto (Geneva, 1904) and The Concentration of Capital (London, 1911). Cherkezov, an orthodox Kropotkinist, argued that Marxism, in predicting the shrinkage of bourgeois society, was not only wrong, but in doing so had set up a deliberate smokescreen to conceal from the workers the desperate situation presaged by the growth of "imperial and military bureaucracies" and the multiplication of individual property ownership. He claimed to have made the first statement (in 1894) of theses which would be at the center of the Revisionist controversy.

2 "Bismarck seriously intended to teach socialism for the strengthening of the German state." Max Nacht [Max Nomad], Unpublished Manuscript (in Polish), 1908, p. 119, Max Nomad Collection.
} 
1880's, Brentano, Held, Schmoller and others. They had allegedly appropriated what little of socialism was required to provide for the orderly growth and enhanced power of the German state. In such a system Social Democracy represented what the elder Liebknecht had called a "party of order" - a phrase to which Machajski often called attention:

"In this way the socialists, like real charlatans, turn both to the bourgeois government and to the workers with the same pleasant smile - convincing the government that trade unions strengthen the workers' servitude while assuring the workers that they are destroying it."1

Trade unions, as the Makhaevists had it, had the defect of producing both a union bureaucracy of conservative officeholders and a labor "aristocracy" of well paid, semi-educated workers. The conservative German economists had hoped to model the German unions on the English unions' sense of "social-pedagogic mission"." And Social Democracy had drowned revolution in this same evangelism of legal unionism: "Marxist doctrine preaches class struggle only against a handful of plutocrats," Machajski charged, "but toward bourgeois society in its progress (the Socialists) feel the most sentimental affection."3 For German Social Democracy, Machajski said, "capitalism" did not designate all of educated bourgeois society but merely a steadily diminishing group of large industrialists and landowners; at most, some violence might be necessary to secure the democratic revolution against them, but from that point on progress would be accomplished by democratic institutions. The Socialists could then appear as the saviours of the national interest: "They worship the greatness of the bourgeois 'fatherland'. They are the best fighters for bourgeois progress." 4

Just as he had seen Marx and Rodbertus in fundamental agreement, Machajski also saw a basic kinship between Marxist Social Democracy and the Socialists of the Chair. The Kathedersozialisten had advised the labor movement to adopt a "realistic" policy toward industrial

1 Rabochii zagovor, p. 56.

2 Podolianin [E. Lozinskii], Klassovaia proletarskaia borba $\mathrm{v}$ strane vsetorzhestvuiushchavo kapitalizma (Moscow, 1906), pp. 8-9. Lozinski was the most prolific of Machajski's Russian popularizers. Here Makhaevist criticism also seems to anticipate the "iron law of oligarchy" thesis, presented in Roberto Michels, Zur Soziologie des Parteiwesens in der Modernen Demokratie (Leipzig, 1911).

3 Rabochii zagovor, p. 52.

Ibid., pp. 51-52. 
relations and the Social Democrats, whatever their rhetoric, were pursuing such a policy. Since they had abondoned the interests of their working class constituents, the Social Democrats had attempted to maintain the appearance of a radical party by proclaiming the goal of democracy. The Makhaevists attempted to convince the workers that the countries already functioning under democratic institutions, particularly England and the United States, were no paradise for the workers. Rather, these countries showed how long the road to the workers' deliverance would be. ${ }^{1}$ The "dialectical" perspective of Marxist socialism was simply a veiled commitment to the slow road of "bourgeois progress".

"Contemporary predatory society, according to the doctrine of the socialists, is not only slavery for the workers but also the preparation of the workers' freedom, the future socialist paradise: capitalist exploitation brings with it socialist equality, capitalist enslavement - socialist freedom... Such double entry bookkeeping necessarily follows from their doctrine."2

In this sense there was similarity between the versions of progress offered by democratic or paternalist Socialism - by Marxist or by Kathedersozialisten - all sought to perpetuate the slavery of the workers by making it serve national needs.

Machajski was particularly concerned that the Russian workers should not become involved in the struggle for political freedom. He always argued that the Russian Socialists operated illegally only because of the impositions of the Tsarist state; they sought only a bourgeois revolution and the freedom to operate in legal parties. ${ }^{3}$ This obvious situation was the basis of his "unmasking" of Russian socialism, which was repeating certain features of the German experience. German Marxism in the 1840's, during a period of "accumulation", had been characterized by a "more or less revolutionary mood", since it was faced with a rapacious bourgeoisie" prepared to reduce all to the

1 Machajski clearly thought that much could be learned from the democratic countries about the future "planned" by the intellectual workers. He seems to have expected the main vehicle of the intelligentsia to be democratic socialism. Nevertheless, he expected the same result - the class rule of the intellectual workers - from different routes : paternalist state socialism, democratic socialism and "Jacobin" forms such as Leninism. The intellectual workers were, in his eyes, the only national class of socialism, with or without free political institutions.

${ }^{2}$ Rabochii zagovor, p. 47.

${ }^{3}$ The standpoint of Trotsky and Helphand-Parvus post 1905 is an exception; like Machajski, they hoped for an immediate social revolution. 
position of wage workers. This militant mood had softened as more and more room in bourgeois society became available to the intellectual workers - hence a similar shift in the character of working class movements this stratum had led. The German party's leadership of the other European Socialist parties was thus explicable in terms other than its theoretical claims; it offered a model for the integration of a huge labor movement into the economic and imperial plans of a powerful nation state. Machajski was impressed, on the other hand, with the revolutionary possibilities of the accumulation period, when presumably even the bourgeoisie thought it could function with a "minimum" state. The impression made by the German statist model of industrial growth after 1870 promised far different results. ${ }^{1}$

For Machajski, the Russian analog of the German "hungry forties" was the period of Populist agitation. Russian Social Democracy which had only surfaced in the 1890's clearly spoke the language of political freedom, in contrast, generally, to its Populist precursors of the 1860's and 1870's, whose attitude had been similar to Machajski's. "The revolutionaries in Russia agreed to begin Social Democracy", he argued, "only at the moment they could emerge as 'a party of bourgeois progress', as opponents of the representatives of workers' revolution, appearing with a program of constitutional government, as a 'party of order'." 2 The main points of their doctrine were "the expediency, advisability and legality of capitalist progress and faith in the trade unionist workers as its carriers" ${ }^{3}$ Even the most radical means, including the general strike, could be approved by them to secure the broadening of the existing areas of political freedom. But, although Russian Social Democrats supported "'revolutionary', 'political' strikes", they were opponents of "strikism"; under which heading they

${ }^{1}$ In this connection we might note that a sense of industrial "reason of state" was prominent among those who, unlike Marxists, hoped for non-capitalist development of Russia. For example, the Legal Populist Vorontsov feared the penetration into government of entrepreneurial ideas of insensate industrial expansion but was nevertheless quite impressed by the "brilliant successes of German industry". "Germany," he thought, "like Russia, is industrially young, and the example of her rapid successes may support the hope that Russia may too follow in her path." (V. V. [Vorontsov], "Promyshlennye uspekhi Germanii", in: Vestnik Evropy (April, 1901,) p. 787.) This is important in order to recognize that Machajski's view of the Russian situation rested on a picture of the rise of democracy in a milieu increasingly concerned with the preservation of national interest throughout the process of industrial development. As a consequence of the exhaustion of the anti-state capacities of West European liberalism, democracy could even be thought of as a kind of étatisme. "... Social Democratic socialism is government socialism, as it exists in democracy." Umstvennyi rabochii, Part II, p. 57.

2 Umstvennyi rabochii, Part I, pp. xi-xii.

3 Ibid., Part I, p. xii. 
put strikes for purely economic demands. ${ }^{1}$ The Socialists had not supported the wave of strikes that spread through South Russia in 1903 just as the Polish Socialists had refused support to the Eódz strike of 1892. Apparently they had not found it in themselves to bring to this task the same enthusiasm with which they had plunged into the student movement.

The Russian Marxists were familiar with this kind of criticism because of the "Economist" controversy; it was answered that since strikes were of importance primarily in building political consciousness, economic strikes lacking a political character served not to broaden among the workers the understanding of the class character of society, but rather to improve and strengthen the hold of the bourgeoisie over them by dissipating their urge for fundamental changes. Machajski stood this familiar argument on its head by suggesting that political rather than economic struggle diverted the revolutionary energies of the proletariat. The purely economic strike was the germ of a slaves' revolt on which he pinned his hopes. It indicated that the distribution of rewards was at issue rather than the existing level of technological and/or political sophistication. Each advance in material conditions won by the strikers would feed their impulse for further advances. The subsequent series of multiplying strikes would then culminate in an expropriatory general strike. Machajski did not claim that his prescription was an intellectual break-through; it had not arisen from a union of "thought" with the proletariat:

"This way has been revealed to the working masses as to all intelligent people; but socialists cannot recall it without hatred. This way is massive economic struggle of the workers and economic general strike."2

In terms of existing categories of revolutionary thought, this sounded like "syndicalism". Machajski never acknowledged even the most obvious similarities between his and other views, but here there were clearly numerous areas in common. French revolutionary syndicalism had also based its doctrine on a reading of Marx which virtually excluded all elements save the class struggle. The syndicalists, too, were "economists", putting the economic struggle ahead of parliamentary activity. There was also their dedication to the expropriatory general strike and their resolve to carry on the struggle even against a collectivist state. Lastly, they shared Machajski's antipathy for the Socialist politicians and lawyers in the labor movement. But however great these tactical affinities, Machajski's critics (and

1 Ibid., Part I, pp. xiv-xvi.

2 Ibid. 
his old friend Żeromski) were wrong to consider him a syndicalist. He was hostile to one of syndicalism's central notions: the capacity of the trade union to function as a replacement for the political party as organ of the workers' interests. Makhaevists suspected that the unionist viewpoint of syndicalism was a kind of backsliding into trade unionism on the English model. ${ }^{1}$ Machajski was both more hostile to parliaments and less hostile to the state than the syndicalists - he did not envision even a subsidiary role for a workers' group in any parliament, and he anticipated the necessity for a government to put into effect demands made by revolutionary workers.

Moreover, his idea of the goal of the workers' revolution was neither to abolish the state nor capture it. At some point in the revolutionary process the owners of industry would, he thought, answer the strikers with lockouts, at which point the state would have to expropriate them in the general interest. This would inaugurate a form of statism under which the workers would continue to press for higher and higher wages until full equality had been reached.

"Taking care of the millionaires and augmenting wages with their wealth, the workers, to further augment these wages, will force the cutting off of all privileged intelligentsia income. By such means the wages of the workers will equal the income of the intelligentsia. Then the children of the manual laborers will have the same resources for education as the children of the 'white hands'."2

The workers would dictate these demands through a "Workers' Conspiracy" on an international scale. ${ }^{3}$ Their interests having finally found a voice, presumably Machajski's. They would proceed to "socialize knowledge" - the final "expropriation" of the intelligentsia. "All will be similarly educated people," he promised, "none will be driven into the life-long slavery of manual labor; there will be no one to rob."4

1 Lozinskii in Protiv techeniia (1907), No 2, p. 15. Lozinskii correctly anticipated the tendency of the French national unions in that direction, a tendency which was given a large push by the replacement after 1908 of the leadership of Griffuelhes, Pouget and Yvetot by that of the "pure syndicalists", led by Leon Jouhaux.

2 Rabochii zagovor, p. 63.

3 Umstvennyi rabochii, Part 1, pp. vii-viii.

- Rabochii zagovor, p. 63. His popularizer Lozinskii imagined a slightly different agency. Committees of delegates should be elected from factories, workshops and from each "more or less significant group" to be "united in a more centralized organization to dictate its demands to the class structure". Protiv techeniia, No 3 (1907), p. 11. 
Machajski's followers imagined that they had a program with which to overthrow the bourgeoisie of all Europe. Their attempts to put it into practice were, however, fragmentary and almost uniformly unsuccessful. In 1902, his followers in Irkutsk published a proclamation calling for a strike movement and denouncing the intelligentsia, the struggle for political freedom and parliamentarism. In 1904 they appeared in Odessa anarchist circles but soon ran into difficulties; among other things, they were suspected of not being sufficiently anarchist. In 1906-07 there briefly existed a "Workers' Conspiracy" in St Petersburg; there was also intermittent conspiratorial activity in Cracow from 1908 until Machajski's arrest in Zakopane in 1911. During the latter period he was closely associated with Max Nomad, then known as Czarny; he was using the name Jan Kiżło when he was arrested. None of these efforts was blessed with any outstanding

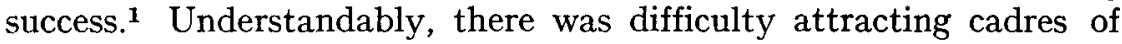
young intellectuals to spread the message and no little suspicion of Machajski himself. He answered those who pointed out that he himself was an intellectual by distinguishing between the class interests of groups like the intelligentsia or the proletariat and the ambitions of certain individuals which might go beyond material comforts. Some of these individuals could legitimately lead other social groups because they were prompted by the lure of fame - of a revolutionary career. ${ }^{2}$ In short, it might be added, because they were capable, in Kautsky's hated phrase, of rising "above the narrow class horizon." To recognize their will to power, however, is not to invalidate the theory; Machajski's aim was not to explain the role of ideas or individuals in social change but to understand the relationship between Socialism and the rise of the new middle class of intellectual workers. Makhaevism is misread if it is reduced to "anti-intellectualism", as it often was in Machajski's time. He knew as well as any Menshevik that the workers' movement required intellectuals as cadres, but he urged, however, that whatever the social composition of its leading forces, that it pursue its own

1 Wiera Machajska, Short History of the Machajski Group, unpublished manuscript, Max Nomad Collection; B. I. Gorev, "Apoliticheskiia i anti-parlamentskiia gruppy (Anarkhisty, maximalisty, Makhaevtsy)", in: Obshchestvennoe dvizhenie v Rossii v nachale XX-go veka (St Petersburg, 1909-14), Vol. 3, p. 525. Gorev reported that they had, however, begun an intellectual trend in Odessa before 1905. He also described a bandit gang Zmowa Robotnicza (Workers' Conspiracy) formed at the same time as the Rabochii Zagovor in St Petersburg; they were simply gunmen operating without the benefit of Makhaevist theory. See Max Nomad, Aspects of Revolt, p. 220-222. Also Pigon, op. cit., pp. 373-80. 2 Max Nomad, "White Collars and Horny Hands", in: Modern Quarterly (Fall, 1932), p. 75. See also his Dreamers, Dynamiters and Demagogues (New York, 1964). 
material interests rather than a chimercial Socialism which stood to benefit only the modern class of white collar workers. He was not really anti-intellectual in the usual sense; it was normal for him to speak of science as "mankind's greatest patrimony". His indignation was directed instead at the hereditary monopoly of this patrimony by a privileged minority. ${ }^{1}$

However, his antipathy for the intelligentsia was not the only reason he was distrusted. Like Bakunin, he expected to find support among the least advantaged sectors of the urban and rural poor, roughly the same future constituency of Bolshevism. When he spoke of the proletariat, he meant the urban manual workers, but he always assumed that his projected uprising would gather together all the poorest elements in the town and village population. Moreover, he saw these groupings, and not the politicized workers, as the exemplars of the revolutionary will. He went to the point of suggesting that the workers should demand of the educated bourgeoisie what brigands did, not ideals or speeches, but their present funds. ${ }^{2}$ Makhaevists also put strong appeals to the unemployed in their publications. The hunger for jobs was as important a fact for them as that of the employed for higher wages. Machajski realized that the increase in real wages which had accompanied the rise of the new middle class in the advanced countries had also been accompanied by a parallel growth in unemployment. He could grant that the workers in countries such as Britain had managed to improve their situation, while also noting the improverished condition of the unemployed whom trade unionism had failed to benefit. In Southern and Eastern Europe, however, not even these minor advances were to be observed; so much the less justifiable then was the appeal of reformist socialism. It might indeed be possible for one of the less advanced countries of Europe to begin a workers' revolution which would trigger similar conflagrations in the more advanced countries.

But the principal force which everywhere impeded such a development was the growth of the middle layers of society, the educated employees of industrial capitalism. They could claim to be above the petty particularism of social class; they alone could discipline the working class and induce it to abandon its true interests to work for a

1 Umstvennyi rabochii, Part I, pp. 73-74.

${ }^{2}$ Rabochii zagovor, pp. 25-26. Makhaevism was consequently called the "class ideal of the lumpenproletariat". See Ivanov-Razumnik, Chto takoe Makshaevshchina? (St Petersburg, 1908), p. 93. Gorev (op. cit., p. 528) also emphasized that aspect. A Stalin era pamphlet showed the most imagination, finding that the "declassed petty-bourgeoisie is the main social-class base of Makhaevshchina." L. Syrkin, Makhaevshchina (Moscow, 1931), p. 62. 
presumed general good. In this perspective Socialism appeared to be merely a movement for national integration. This was Machajski's main reason for comparing Marx with Rodbertus. This was the tendency he observed in the development of German Social Democracy and in its positivist, historicist intellectual baggage; he could find it in the early writings of Marx, as an imperfectly developed, vague sort of idealistic social holism of "one society" and also in the more fully developed scientism of Engels and Kautsky; it had permeated Russian Socialism as well. Its most attractive mask was a democracy that would preserve the general interest. ${ }^{1}$ The Workers' Conspiracy on the other hand was distinguishable for its expression of a workers' will which would not wait until it became a democratic majority to defend its interests. The Socialism which claimed to express the will of the "people" or the "nation" as a social whole, was only a "new means of rule". ${ }^{2}$ Only such a social holism could seriously posit a workers' state which could have interests distinguishable from the material interests of the workers themselves.

\section{IV}

Machajski's arrest at Zakopane in 1911 ended his activity for a considerable time. Since 1904 he had been complaining about losing his ardor for political activity; the Zakopane affair apparently convinced him of the advisability of a gracious exit from the revolutionary struggle. When the Russian revolution began in February 1917, Machajski was working in a bank in Paris. He returned to Russia later in the year and in the Spring of 1918 wrote and published one

1 In the light of Machajski's critique it is interesting to consider these words of Martov's directed against Bolshevism: "An effective force concentrated in the State, which can thus realize the conscious will of the majority despite the resistance of an economically powerful minority - here is the dictatorship of the proletariat. It can be nothing else than that in light of the teachings of Marx. Not only must a dictatorship adapt itself to a democratic regime, but it can only exist in the framework of democracy, that is, under conditions where there is the full exercise of absolute political equality on the part of all citizens. Such a dictatorship can only be conceived in a situation where the proletariat has effectively united about itself 'all the healthy elements' of the nation, that is, all those that cannot but benefit by the program of the proletariat. It can only be established when historic development will have brought all the healthy elements to recognize the advantage to them of this transformation. The government embodying such a 'dictatorship' will be, in the full sense of the term, a 'national government'." I. Martov, Mirovoi bol'shevizm (Berlin, 1923), pp. 107-108.

2 Umstvennyi rabochii, Part II, p. 56. 
number of a revolutionary journal, Rabochaia revoliutsiia. Its view of the Bolshevik regime was not simply a reflex of his previous views on Socialism; Machajski recognized that the Bolsheviks were something special. Still, his attitude toward Bolshevism was consistent with the theory of Makhaevism. The fall of Tsarism was, in his view, the signal for a series of revolts against modern society, now engaged in the reductio ad absurdum of the mastery of technology by national interest - modern war. As his wife recalls, his personal feelings in 1917 served to strengthen a life-long disposition, "Always and everywhere, a bas la patrie." $\mathrm{He}$ had written earlier that Marxism spoke for

"one single humanity, that very same humanity which in the primeval wars directed all the power of its mind toward the invention of instruments for mutual extermination and enslavement, which throughout the ages has been engaged in perfecting the enslavement of the majority of the human race." 2

Machajski applauded the defection of the Russian workers from the war effort, hoping that it would trigger mutinies in the other armies. He was probably influenced by the international general strike which began in Budapest in January 1918, spreading eventually to Vienna and Berlin. The Bolsheviks, especially Bukharin's group, had pinned their hopes for evading the German peace terms on these uprisings. Although they proved to be inadequate to that task, they no doubt strengthened Machajski's conviction that "the international struggle against war can occur only as a workers' revolution."3 As leaders in the struggle, the Russian workers were to be congratulated for breaking the "vicious cycle of endless international slaughter". 4 Their desertion from the war effort had broken the backs of the intelligentsia parties, competing for power behind a screen of oratory about democracy.

The principal divergence between the will of the workers and that of the Provisional Government had been, according to Machajski, the desire of the latter to limit the revolution to the establishment of free democratic institutions on the model of Western Europe, while preserving Russia's role as a major power. The workers did not admire such "great power robbers" who only wanted to dampen their revolutionary impulses. "They want a world-wide struggle against exploitation", capable of expelling both the "crowned and republican

1 Wiera Machajska, “Źycie i poglądy Wacława Machajskiego”, p. 3.

2 "Primechaniia perevodchika", pp. 53-54.

3 Rabochaia revoliutsiia, p. 28.

4 Ibid., p. 1. 
thieves". 1 Bolshevism was the only intelligentsia force willing to ally itself with such an outburst.

"The Bolshevik party correctly calculated the strength of the ripening revolutionary spontaneity, endeavoring to annex it. By means of its slogan 'All power to the Soviets' it rallied the nationwide insurrection to its goals and convinced the masses that Soviet power would be the power of the working class and the poorest peasants."2

To a considerable degree, the Bolsheviks performed according to the choreography Machajski had laid out in his previous writings on the revolution and the state: the workers were not to seize the state but press it to put their demands into effect - the state was to make the requisite expropriations and initiate public works projects in a presumably harried attempt to find areas of agreement between its own national interest and the "workers' will". The workers, he noted, had enthusiastically hailed the seizure of state power by the Bolsheviks and the ensuing series of measures against the bourgeoisie. They were delighted that the Bolsheviks took steps against "the richer and wrecking intelligentsia", moved to conclude peace, overthrew the "lordly" (gospodskoi) officer caste, suppressed the bourgeois press and generally destroyed the momentum of "collected institutions" - the bourgeois parties, their presses, the Constituent Assembly - those he had previously decried under the rubric of "bourgeois progress".

This area of agreement with Bolshevism was at least partly a product of a shared hostility to the principles of democratic socialism, for Machajski a hostility based "on principle"; for Lenin, less so. It is curious, moreover, that much of the socialist criticism of the 1917 Lenin was quite similar to that levelled earlier at Machajski. For example, Martov thought the successes of Leninism to be in part the work of the least advanced sectors of the proletariat, the chernorabochii brought into the city as replacements for the most politically advanced workers who had been sent to the front. ${ }^{3}$ A Russian Socialist who knew Machajski in exile commented similarly:

"I might remark that despite myself I was struck by the analogy between the Bolsheviks after 1917 and Makhaevshchina: the similarity in method and content of the critique of Social Democracy, as in the unleashing of 'hunger revolts' (the Leninist

1 Ibid., p. 2.

${ }^{2}$ Ibid.

3 I. Martov, op. cit., pp. 13-14. 
'robbing the robbers', the 'liquidation of the bourgeoisie', the baiting of the intelligentsia)."1

While he appreciated the difference between Leninism and democratic Socialism, Machajski was not one of those who thought that Lenin had abandoned Marxism by taking action in October 1917.

"As opposed to the Social Democrats, who insist on parliamentarism, the Bolsheviks, in word and deed, are true to the Marxist form of seizing power." 2

He had not always given Lenin this much credit. The founder of Bolshevism had not been Machajski's major target among the Russian socialists. In 1905, in the introduction to the Intellectual Worker, he had called the Leninist "conspiracy" an "empty daydream useless even for putting pressure on the autocracy, let alone for establishing a 'Democratic Dictatorship of the proletariat and peasantry' ". $3 \mathrm{Ma}$ chajski was not at that time principally concerned to distinguish the democracy of the parliamentary-minded Socialists from the "democratic dictatorship" of the Leninists, since he thought such a distinction to be unimportant for the workers. What was more important was that both were proponents of the bourgeois revolution in varied styles of democratic dress, that both would subordinate the economic demands of the workers to political tasks - the conquest of the autocracy; for Machajski the fall of the autocracy should, on the contrary, be the by-product of social revolution. But at that time Machajski thought Leninism inadequate even to its own tasks and wondered whether the circumstances didn't suggest that Iskra appoint "for the attack on Autocracy, some democratic general".4

The reference to the "Marxist form of seizing power" makes clear what Machajski considered the important difference between Communism and democratic socialism. He had argued in The Evolution of Social Democracy that Communism could be expressive of a worker's will.

1 P. A. Garvi, Vospominaniia sotsialdemokrata (New York, 1946), pp. 291-92. Garvi added, however, that "on the other side, the party dictatorship of the Bolsheviks, the party dictatorship over the proletariat, justified Machajski's prediction of the danger of the accession to power, in place of the bourgeoisie, of the 'Intellectual Workers', engineers, and technicians, organizers of the economy masquerading as socialists."

2 Rabochaia revoliutsiia, p. 7.

${ }^{3}$ Umstvennyi rabochii, Part I, pp. xxii-xxiv.

4 Ibid., Part I, p. xxiii. 
"The Communist Manifesto called for a permanent revolution. This means: while the democrats express the 'popular will' in democratic institutions and laws, in which may only be manifested for them the will of differing layers of the population, the communists aim at a dictatorship of the proletariat but do not mean submission to the 'popular will' in whatever democratic forms may be advanced. They do not think to stake the fate of the proletariat on dependence on the evolution of this democratic 'will of the majority' (as do the Social Democrats), but rather in the expression of a proletarian will apart from that of a national majority. They stake the fate of the proletariat exclusively on dependence on its own power."1

Although this was a position which Marx and Engels approached rhetorically only at certain moments during their association with the Communist League of the 1840's, it was the standard by which Machajski had judged the Socialist parties of his time. However, he came to oppose even this messianic dream, settling on the view that the doctrine of class struggle was hopelessly at variance with the statist elements in Marx's theories, even when it had appeared most ostentatiously. He concluded finally that "The Communist Manifesto was the most profound and viable formula of the 'democratic' socialism of the ... European Intelligentsia."2

The pursuit of political freedom was to him the identifying characteristic of Socialist politics, but it was not the only one. There was also Machajski's hostility to all forms of Jacobinism, as well as to Bolshevism. ${ }^{3}$ Therefore, he rejected any notion of a workers' dictatorship in the form of a state, since a state must have a national interest apart from that of the working masses: "Any socialism tends to liberate the intelligentsia, but not the workers." 4 The Bolsheviks, having assumed a monopoly on the interests of the working class, and identifying that with the state, as a "workers' state", would now oppose any spontaneity of the workers against "their own" state. ${ }^{5}$ Machajski predicted that future manifestations of the will of the proletariat against the Soviet state would be attributed to the hooliganism of a criminal element in the working class. He charged that the highest goals to which the Bolsheviks aspired revolved around the "democratization" of bourgeois society, not its destruction. The Communist

1 Umstvennyi rabochii, Part I, pp. 15-16.

2 Bankrotstvo sotsializma XIX stoletiia, p. 26.

s Ibid., p. 30.

4 Rabochaia revoliutsiia, p. 20.

s Ibid., p. 13. 
Manifesto had provided both models of Marxist politics: JacobinBlanquist and parliamentary - and both models were "democratic". 1 As a result the Bolshevik dictatorship would preserve bourgeois society "in a new form", under which the role of the masses would be "not qualitatively different because of the transition from the old bureaucracy to the new".

This antipathy to all state forms should not obscure the fact that Machajski's "workers' revolution" required some kind of state to put its demands into effect. There was in this sense room for the Bolshevik dictatorship in Machajski's scenario. "Enough", he said, "of seeking some ideal power, better than the Soviets"; the workers must defend the dictatorship. "An iron ring of counter-revolution", he warned, "encircles the Soviet Republic, and threatens to strangle the Russian revolt against plunder and war." 3 Such a defense had, moreover, to be taken up without illusions. The Bolsheviks had come far enough with the workers while they were seeking power, but now they were drawing back, attempting to restrain and discipline, hence to control, the revolution. His bill of particulars was quite similar to that of the anarchists: 4 he was unhappy that a regular army was being formed; that up to the time he wrote, only a handful of enterprises had been nationalized; that the Bolsheviks had already retreated from their previous promises about workers' control of production; and that, in the final analysis, they had decided to meet the power of the counterrevolution with the power of the state rather than with that of the proletariat: "These same Communists decided not to have a workers' revolution and instead to restrain the workers' mutiny under dictatorial decisions." 5 Still, he urged defense of the Soviet dictatorship, against the Whites and against the "intelligentsia counter-revolution".

The counter-revolution had from the outset taken the form of "stubborn intelligentsia sabotage" directed against the Bolshevik regime. ${ }^{6}$ Machajski referred to the resistance of government employees

1 Umstvennyi rabochii, Part II, p. 20.

2 Rabochaia revoliutsiia, pp. 12, 26.

3 Ibid., p. 1.

4 He was, however, quite critical of the attempts of the anarchists to organize the revolution because, he said, they had not been able to advance the workers' interests any further than Bolshevism (Ibid., pp. 22-24). Here, he spoke in different terms, although hardly less harsh, than those he had used earlier to speak of the anarchism of the Khleb $i$ Volia type, which, he correctly claimed, did not look further than the bourgeois revolution. Such criticism was one of the tasks of The Intellectual Worker. See also Podolianin [Lozinskii], Sovremennyi anarkhizm (Moscow, 1906), p. 9.

5 Rabochaia revoliutsiia, p. 2.

Ibid., p. 5. 
who had withheld keys to offices and files, organizing a strike in November, 1917, under the direction of their union. The State Bank officials had attempted to withhold cash reserves from the government and had also gone on strike. An army of intellectual workers, supported by strike funds gathered from various sources including private businessmen, "complained that the Bolsheviks were terrorizing them." Machajski noted with satisfaction that three months of Soviet dictatorship had managed to break this strike, achieving control over these "intelligentsia strikers and saboteurs". ${ }^{1}$ Still other groups of "intelligentsia wreckers" - Mensheviks and SR's - were now, he charged, fighting among the ranks of the counter-revolution, resulting in the ludicrous spectacle of the workers shedding their blood to defend the Bolsheviks from their "socialist opponents".

Although the workers must defend the dictatorship they must not do so by submitting to its discipline - here Machajski touched on a point which divided the ranks of the anarchists - but rather by broadening the social revolution. They must demand immediate expropriation of the big and middle bourgeoisie, putting a low ceiling not only on the incomes of the small enterprises but on the personal incomes of the intellectual workers. The resulting funds, including the cash reserves of banks should be used to augment wages, especially for the unskilled workers, and to provide jobs for the unemployed. But he warned that when the Bolsheviks did perform the necessary expropriations, they would save all the profits for state use, excusing themselves with the explanation that actual material improvement of the workers' lives would have to wait for the advent of Socialism. ${ }^{3}$ These expropriations should be but the first stage in the social revolution; after the bourgeoisie, there remained the intelligentsia. Only by making dramatic material gains for the workers themselves could the revolution save itself and spread to other capitalist countries. "The Kaiser", he said, "cannot restore capitalism", but the workers could retire him! ${ }^{4}$

Machajski variously referred to the Bolsheviks as "petty-bourgeois" and "intelligents and half-intelligents", but obviously they were not the typical intelligentsia Socialists of the era of the Second International and, therefore, he expected more from them. ${ }^{5}$ The difference for

1 Ibid., pp. 15-16.

2 Ibid., p. 17.

s Ibid., pp. 21, 31.

4 Ibid., p. 2.

- See Max Strypyansky [Max Nomad], "Non-Conformists of the Russian Revolution", in: Soviet Russia, Vol. 5, No 1 (July, 1921), p. 31; "part of [Machajski's] predictions had not come true - viz. the Bolsheviks had turned out to be better than he expected and he was not sorry." 
him was between the "Jacobin-Blanquist" model of revolutionism (which the Bolsheviks represented momentarily) and that of the years of Marxism's linkage to the democratic labor movement. What for him was common to these two models was the conviction, traceable to the Teachers themselves, that under the appropriate objective conditions, only the Marxist version of social revolution could produce a truly national government. For Machajski this idea of the destiny of the proletariat - to restore to society the unity lost by the era of capitalist industrialization - should have been subordinated to the truly revolutionary idea of the class struggle. That Marxism had been unable, in the end, to effect such a subordination indicated that it had not been capable of going beyond the promise of early Socialism to rescue society from the ravages of the industrialization process. Even the most revolutionary Marxism once it had taken power in a single country was finally destined to propound a national interest distinguishable from that of the class which gave it power. This, of course, is not by any means to suggest that he accused the Bolsheviks of being "nationalists". There was, however, in Machajski's critique, the implication that the workers' interests, once having been subordinated to those of this new version of society-as-a-whole, could be still further subordinated to tasks national or international which would postpone the social revolution ad infinitum. Having risen above the narrow class standpoint, the intelligentsia could raise its sights still further to the "utopianism of one humanity"; this was the character of its brand of proletarian internationalism.

It was during the period of the rise of a technical and administrative elite to positions of importance during the 1920's and 1930's, that the Soviet regime attempted to review the ideas of the little known Machajski, who having retired to a proof reading job on the periodical Narodnoe khoziaistvo, died in Moscow in 1926. Makhaevism was identified consistently with official versions of supposedly moderate and non-political forms of labor agitation of the pre-1905 period, particularly the trend within Social Democracy which came to be called Economism and the experiments in police unionism, The Zubatorshchina. Emel'ian Yaroslavskii wrote that

"The anarchism of the Makhayevites was something between 'economism' and 'Zubatovism'. For example, Makhayev 
[Machajski] tried to convince the workers that they could reach a standard equal to the profits of the capitalists."1

It is possible to argue that what Leninist literature called "Economism" as well as the experiments in police unionism were in a sense reflections of a conflict between two goals: that of the Social Democrats to achieve political freedom and that of the urban working class to improve its material conditions - a rift which could be seen at least from the time of the spontaneous strikes of textile workers in St Petersburg in 1896-97. Further, strictures against the intelligentsia were a feature common in differing degrees to both the agitation of Makhaevism and the other two manifestations. Both of the latter, however, sought to use such agitational activities for ends outside the context of Makhaevism - "Economism" ultimately to overthrow the autocracy, Zubatovshchina to save it. Machajski, as we have been arguing, thought the fall of Tsardom would be a by-product of the destruction of bourgeois society, and was fully as hostile to legal trade unions, prominent in the plans of both Economism and the Zubatovshchina, as to parliamentarism. We are left then with the assertion, made by Yaroslavsky and others, that the means of the three trends (economic struggle and its corollary anti-intellectualism) were similar and that they were moderating influences which tended to dissipate the resistance of the workers to the existing political and industrial order, by promising them, for example, that they could reach a "standard equal to the profits of the capitalists".

However, whatever anti-intellectualism could be found among the Economists was not sufficient to blot out their basically political goals. Those who came closest to deserving the Economist label, S. N. Prokopovich and E. D. Kuskova, prescribed that the workers' activity for economic advance be accompanied by intelligentsia efforts to find a coalition with forces seeking a constitution. Even the group around the periodical Rabochaia mysl', much closer to the syndicalist mood, still thought that the challenge to government and society offered by the economic movement could help secure political freedom. Rabochaia mysl' had for a time counseled against worker support for the wave of student strikes for the maintenance of the corporate status of the universities, but it did not do so to make the workers' movement more acceptable to the existing political order. By what means, asked Rabochaia mysl' in 1898, could the workers' interests be advanced, legal or illegal? It answered, "By all means!", and included among

${ }^{1}$ E. Yaroslavsky, History of Anarchism in Russia (New York, 1937), p. 39. See also L. Syrkin, op. cit., pp. 53-55. 
these "massive strikes for increases in wages and shortening of the work day", secret workers' societies, "Unions for Struggle for the Liberation of the Working Class", and "criminal proclamations". ${ }^{1}$ When, in 1901, it adopted a more friendly attitude toward the student movement, it demanded "freedom ... first of all freedom to strike, free unions and assemblies, personal freedom, freedom of speech and press". It recommended that the workers proceed from partial actions "to massive strikes and political demonstrations against the whole capitalist class, against the whole political structure". ${ }^{2}$ Whatever anti-intellectualism existed among the Economists reflected neither a class analysis of the intelligentsia nor an aversion to the struggle for political freedom. That this position was different from Makhaevism can be seen when it is recognized that Machajski claimed to have no political goals at all, and that the struggle for political freedom was positively alien to the workers' cause. He thought that his conspiracy would exist illegally under democracy as under autocracy.

On the other hand the anti-intellectualism of the Zubatov unions was part of an effort to direct the labor movement away from the attack on autocracy by forming non-political unions barring intellectuals. Zubatov's frame of reference was not the capitalist industrial order but the polity of Tsardom, devotion to which put his work into conflict with what he termed "so-called educated Russian society". ${ }^{3}$ As he saw it, his work was less to accommodate the workers to the discipline demanded by the new capitalist industrial system than to provide a check on the power of those classes which might profit most from industrialization - a check for the benefit of the autocracy. ${ }^{4}$ Zubatov once said: "I categorically declare that I am in principle opposed to strikes." Strikes were only resorted to, he claimed, because of competition from the revolutionaries or "the crudity of the jewbosses". ${ }^{5}$ His experiences seem to offer little proof that working class militancy was effectively dampened when workers were engaged in his style of economic action. Zubatovist workers, on the contrary, sometimes proved to be quite difficult to control. This was especially the case with the strikes in South Russia in 1903, as Dr Shaevich, the police agent in Odessa who initiated the movement quickly learned. The parallels drawn by Marxist criticism of Machajski's ideas seem to imply a thesis different from the intended one: that Russia's new

${ }^{1}$ Rabochaia mysl', No 4 (October 1898), p. 1.

2 Ibid., No 11 (April, 1901), p. 1.

3 S. Zubatov, "Zubatovshchina", in: Byloe, No 4 (October, 1917), p. 175.

" On some of the experiences of the Zubatovshchina, see " $K$ istorii Zubatovshchiny", in: Byloe, No 1 (July, 1917), pp. 86-99.

5 Ibid., p. 95. 
industrial working class of the pre-1905 period was more closely acclimated to the ethical-paternal social pattern of the Tsarist order than to the practical world of daily political and economic struggle within a modern industrial order. Under these circumstances economic struggle might have just as explosive a revolutionary potential as political struggle. If it was true that the normal inclinations of the workers were for material improvement rather than political liberation, it was not by any means clear that these inclinations could be kept within the normal limits of a functioning industrial system given Tsarism's uncertain support for such a system and the presence in it of so many foreign firms - to name but two factors. The tendency to lump Makhaevism with Economism and the Zubatovshchina was of course correct enough insofar as the primacy of the economic struggle characterized all three movements. The argument overlooks, however, the possibility of a non-political revolutionary economism - as though French revolutionary syndicalism had never existed - largely because of the conviction, not limited to Marxists, that the workers of themselves are only capable of developing a trade-union consciousness. Makhaevism can never be claimed as support for that thesis.

Without slighting the originality of Machajski's theory, it can also be recognized that it was a synthesis of diverse elements, none of whose contributions was ever acknowledged by Machajski. On the analytical side the economic definition of the intelligentsia had been approached by a number of Russian Populists. We have already noted the important influence of Bakunin. P. N. Tkachev was also of a temperament quite close to Machajski's on this question. He had argued, from his own understanding of Marxism, for a social revolution which would effect the most extreme levelling of the cultural and technical education of the population to the extent of holding back bright students. Such a revolution had moreover to be made immediately before it was undermined by economic progress. He agreed with Nechaev's dictum: "It's real rubbish to go to school, because all the educated people invariably become exploiters and the process of learning is in itself a form of exploitation."1 A Populist of the 1880's, Iuzov-Kablits had asked: "What is the intelligentsia? ... The most general and indeed the only criterion is that of intellectual work. Whoever lives not by physical work but by mental work counts himself among the intelligentsia and has the right to do so."2 His goal was to prevent the intelligentsia from contaminating the masses with its

${ }^{1}$ Quoted in B. P. Koz'min, P. N. Tkachev i revoliutsionnoe dvizhenie $1860-\mathrm{kh}$ godov (Moscow, 1922), pp. 193-94.

Kablits [Iuzov], Intelligentsia i narod (St Petersburg, 1886), p. 73. 
"bureaucratic ways" and its "economic and juridicial influence"." The Legal Populist Vorontsov also warned that "the intelligentsia, as a creative social agent, possesses as much strength in practice as the class to which it belongs."2

On the prescriptive side the call for a "workers' revolution" based on the broadening of the economic strike movement was a tactic of revolutionary syndicalism as of Bakunism. In this sense it is possible to think of Machajski as part of the anarchist tradition, something he would never have accepted. But a most important link to that tradition was the consistent anti-patriotism which he applied to criticism of the Polish "social patriots" and of Marxism itself. In this way it was possible for him to call for a workers' revolt against the national interest whether it was masquerading in the "szlachta" guise or under the banner of revolutionary Marxism.

1 Ibid., pp. 106-107, 129.

${ }^{2} \mathrm{~V}$. V. [Vorontsov], Nashi napravleniia, p. 68, quoted in Ivanov-Razumnik, Chto takoe Makhaevshchina? (St Petersburg, 1908), p. 12. 